
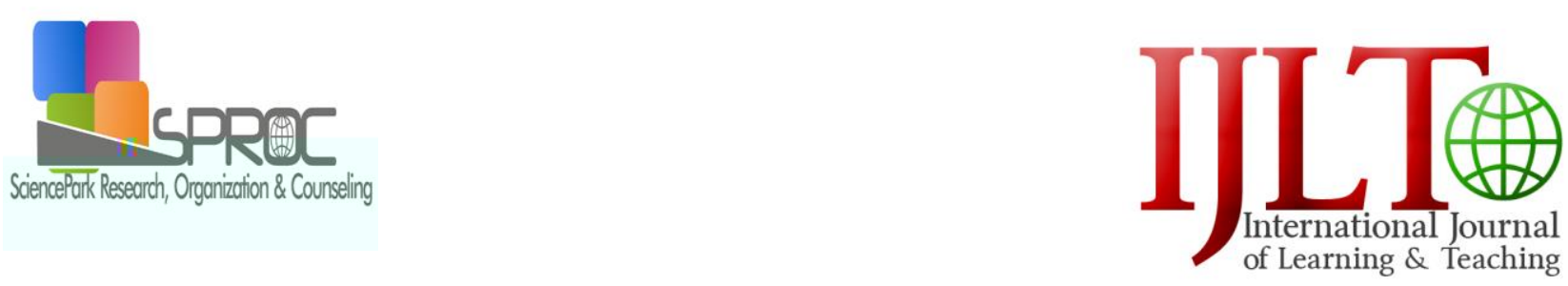

www.ij-lt.eu

\title{
Comparison of the advanced theory of mind skills in Turkish Children with autism and typically developing children
}

Alev Girli*,

Suggested Citation

International Journal of Learning and Teaching 9

Abstract

Alev Girli, 
International Journal of Learning and Teaching 9

1. Introduction 
International Journal of Learning and Teaching 9 
International Journal of Learning and Teaching 9

\section{Method}

\subsection{Participants}

2.1.1. Inclusion and exclusion criteria

2.2. Instruments

2.2.1. Prerequisite instruments 
International Journal of Learning and Teaching 9

2.2.2. Research Instruments 
International Journal of Learning and Teaching 9

\subsubsection{Procedure}


International Journal of Learning and Teaching 9

2.2.4. Reliability

3. Results and Discussion

$* P$ 
International Journal of Learning and Teaching 9

312 


\section{Limitations and Recommendations}

\section{Acknowledgments}

\section{References}

Diagnostic and statistical manual of mental disorders

Developmental Psychology, 35 ,

Yuksek Fonksiyonlu Otistik Cocuklarda Cesitli Bilissel Ozelliklerin Incelenmesi

Journal of Autism and Developmental Disorders, 19

Child Psychology and Psychiatry, 30

Journal of

Child Development, 62

Journal of Child Psychology

and Psychiatry

21

Cognition,

Visual Cognition, 4

Journal of Child Psychology and Psychiatry, 42

Poster

presented at the 13th European Conference on Developmental Psychology 
European Journal of Developmental Psychology, 7

. Autism, 8

Child's talk: learning to use language

Social

Development 11

Journal of Experimental Child Psychology, 104

Journal of Child Psychology and Psychiatry, 45

Psychological Bulletin, 115

Journal of Autism and Developmental Disorders; 35

Journal of Logic, Language and Information, 17

Journal of Autism and Developmental Disorders 36

Ileri Duzey Zihin Kurami Testleri ile Otizmli ve Tipik Gelisim Gosteren Cocuklarin Zihin Kurami Duzeylerinin Incelenmesi

Psychology, 5

Procedia-Social and Behavioral Sciences, 2, 1951-1954.

Education and Their Implications

2nd International Conference on New Trends in

Developmental Disorders 38

Journal of Autism and The Relationship Between Metacognitive Vocabulary and Theory of Mind Development

Autism 9

Developmental Disorders 24

Journal of Autism and 
Cognition and Emotion, 19

Child Development 57

Research in Autism Spectrum Disorders, 8,

Teaching children with autism to mind-read: A practical guide

Social Development, 13

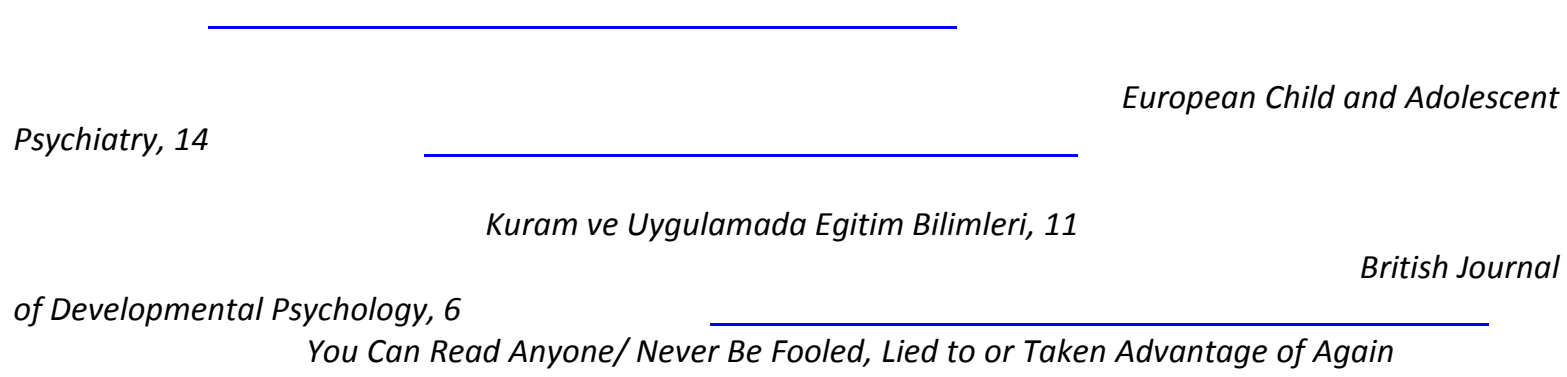

Developmental Psychology, 44

Turkiye'de kullanilan psikolojik testlerden ornekler

Journal of Autism and Developmental Disorders 25

Journal of Child Psychology and Psychiatry 32

Journal of Experimental Child Psychology, 39

Child Development 60

British Journal of Developmental Psychology, 5

A pilot study of social cognition training for adults with high functioning autism

Research in Autism Spectrum Disorders, 3

Child Development, 76

1

Behavioral and Brain Sciences, 
Zihin Kurami Hikayeleri Testi'nin Turk Cocuklarina Uyarlanmasi ve Okuloncesi Donemdeki Normal Gelisim Gosteren, Zihin Engelli ve Otizmli Cocuklarin Zihin Kurami Gelisimlerinin Karsilastirilmasi

$$
\text { Journal of Autism and Developmental Disorders, } 40
$$

International conference on new trends in Education and Their implications

Child Development 72

The child's theory of mind.

Child Development, 80

Cognition 13

"Journal of Applied Developmental Psychology; Special Issue on Child Abandonment" 26

20

Turkish Journal of Psychology

Turk Psikiyatri Dergisi 22

Journal of Autism and Developmental Disorders, 